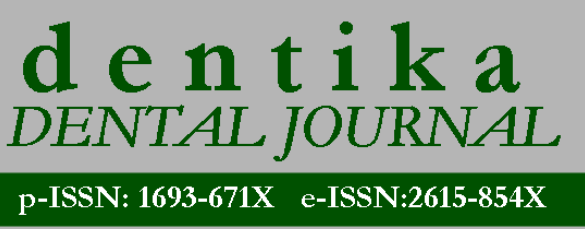

\title{
Streptococcus mutans Antibacterial Activity of $0.1 \%$ Lysozyme Tooth Paste as an Alternative for Children Below 3 Years Old in Preventing Early Childhood Caries (ECC) (Experimental Laboratory Study)
}

\author{
Aktivitas Antibakteri Streptococcus mutans dari Pasta Gigi Lisozim 0,1\% \\ Sebagai Alternatif Untuk Anak Di Bawah 3 Tahun \\ Dalam Mencegah Karies Anak Usia Dini (PAUD) \\ (Studi Laboratorium Eksperimental)
}

\section{Essie Octiara $^{1}$, Heriandi Sutadi ${ }^{2}$, Yahwardiah Siregar ${ }^{3}$, Ameta Primasari ${ }^{4}$}

\author{
${ }^{1}$ Department of Pediatric Dentistry, \\ Faculty of Dentistry, Universitas Sumatera Utara, Jl. Alumni no. 2, Medan 20155, Indonesia \\ ${ }^{2}$ Department of Pediatric Dentistry, Faculty of Dentistry, \\ Universitas Indonesia, Jl Salemba Raya no. 4, Jakarta 10430, Indonesia \\ ${ }^{3}$ Department of Biochemistry, Faculty of Medicine, \\ Universitas Sumatera Utara, Jl. Dr. T Mansur no. 5, Medan 20155, Indonesia \\ ${ }^{4}$ Department of Oral Biology, Faculty of Dentistry, \\ Universitas Sumatera Utara, Jl. Alumni no.2, Medan 20155, Indonesia \\ Email: essie.octiara@usu.ac.id
}

\begin{abstract}
One of the ways of preventing Early Childhood Caries (ECC) is by removing tooth debris through the use of fluoride toothpaste. However, its use by children below 3 years old needs to follow recommended quantity due to the possibility of being ingested, thereby causing fluorosis. Lysozyme has potential to be fluoride substitution as it mediates bacterial aggregation, inhibits adhesion, and activates autolysin by destructing their cell wall. Therefore, this study aims to compare Streptococcus mutans' antimicrobial activity of non-fluoride lysozyme toothpaste of various concentrations such as 0.025 , $0.05,0.1$, and $0.2 \%$. This experimental study was conducted using a post-test design and the tested toothpaste was lysozyme-contained with $0.025,0.05,0.1$, and $0.2 \%$ concentrations. Meanwhile, children toothpaste containing fluoride, enzyme, and $0.2 \%$ chlorhexidine were used as the positive control. The test of $S$. mutans antibacterial activity used 3 methods, namely disc diffusion, well, and microtiter plate. The analytical test used Anova one way with Bonferroni post hoc and $\mathrm{p}<0.05$ significant level. The results showed that all concentrations of lysozyme toothpaste had an inhibitory effect on the growth of $S$. mutans ( $\mathrm{p}<0.05$ ), while the highest mean was on 0.1 and $0.2 \%$ concentrations. This showed that a $0.1 \%$ concentration of lysozyme toothpaste can be used as an alternative for children below 3 years old.
\end{abstract}

Keywords: Early Childhood Caries (ECC), Lysozyme Tooth Paste, Antibacterial Activity, Streptococcus mutans

\begin{abstract}
Abstrak
Salah satu pencegahan ECC yang efektif adalah membersihkan gigi dari debris. Penggunaan pasta gigi berfluor pada anak di bawah usia 3 tahun harus dengan jumlah yang disarankan, karena dapat tertelan sehingga menyebabkan fluorosis. Lisozim sebagai zat aktif dalam pasta gigi mempunyai kemampuan memediasi agregasi bakteri dan menghambat perlekatan bakteri dan juga mengaktifkan autolisin bakteri dengan menghancurkan dinding sel bakteri. Tujuan penelitian ini membandingkan daya aktivitas antimikroba Streptococcus mutans dari pasta gigi lisozim tanpa fluor dengan berbagai konsentrasi $0,025 \% ; 0,05 \%, 0,1 \%, 0,2 \%$ dan $0,4 \%$. Jenis penelitian adalah eksperimen dengan rancangan post test only. Pasta gigi yang dicoba adalah pasta gigi lisozim dengan konsentrasi $0,025 \% ; 0,05 \% ; 0,1 \%$ dan $0,2 \%$. Pasta gigi anak berfluor, pasta gigi enzim dan chlorheksidin $0,2 \%$ merupakan kontrol positif. Uji aktivitas antibakteri S.mutans digunakan 3 metode yaitu metode difusi dengan disc dan sumuran serta microtiter plate. Uji analisis digunakan Anova one way dengan post hoc Bonferoni dan tingkat kemaknaan $\mathrm{p}<0,05$. Hasil penelitian diperoleh semua konsentrasi pasta gigi lisozim memiliki daya hambat terhadap pertumbuhan S.mutans $(\mathrm{p}<0,05)$. Rerata aktivitas antibakteri S.mutans yang terbesar
\end{abstract}


dimiliki oleh pasta gigi lisozim konsentrasi $0,1 \%$ dan $0,2 \%$. Disimpulkan pasta gigi lisozim konsentrasi $0,1 \%$ dapat digunakan sebagai pasta gigi alternatif untuk anak usia di bawah 3 tahun.

Kata kunci: ECC, pasta gigi lisozim, aktivitas antimikroba, S.mutans

\section{INTRODUCTION}

According to the American Academy of Pediatric Dentistry (AAPD), tooth caries at an early age is the presence of caries lesion on the surface of deciduous teeth (cavities or non-cavities), tooth loss due to caries, or filled teeth on children under 6 years old. ${ }^{1}$ Several countries including Indonesia have discovered a high prevalence of ECC cases in 2 years old children with $27.66 \%$ in China $^{2}$, Srilanka $32.19 \%,{ }^{3}$ and $68.5 \%$ in Northern Thailand ${ }^{4}$. Based on national data, there is an increase in caries prevalence among Indonesian children. According to Riskesdas 2007, the cases were $6.9 \%$ in children of the $1-4$ years old age group, while in 2013, 10.4\% was reported., However, the ECC prevalence was higher than national data, which was $57.7 \%$ in Medan. ${ }^{7}$

The high prevalence of ECC on early-age children has drawn health workers' attention, especially the pediatric dentist. Therefore, regular removal of debris from teeth has been found as an effective way of preventing ECC. The habit of brushing teeth is properly carried out after the first tooth eruption. ${ }^{1} \mathrm{In} \mathrm{Li}$ thuania, a study has shown that children who brushed their teeth since the first tooth eruption had lower ECC risk. ${ }^{8}$ Similarly, mothers who brushed their children's teeth since the beginning of eruption had more caries-free children $(\mathrm{p}=0.007) .{ }^{9}$ In Indonesia, the APPD recommended that fluoride-containing toothpaste use for children below 3 years old needs to be only the size of rice and not exceed the size of a bean for children between the ages of 3 to 6 years. ${ }^{10}$

This was intended to prevent the risk of paste ingestion, which might cause fluorosis. ${ }^{11}$ Children below 1 year of age can also have their teeth cleaned by using a smooth toothbrush without paste or using non-fluoride toothpaste. ${ }^{10}$ A previous study on 6-71 months old children showed that more children using fluoride-containing toothpaste were not affected by ECC $(85.8 \%)$ compared to $14.2 \%$ who were were affected. ${ }^{12}$

Although toothpaste quantity given to early age children is limited, some parents are still worried about using fluoride-containing toothpaste on children of 2 years old and below because of ingestion. Therefore, the non-fluoride type that still contains
Streptococcus mutans (S. mutans) antibacterial active substance can be given as an alternative.

Lysozyme as an innate immunity in saliva became first and prominent body defense in the oral cavity..$^{13}$ It is antibacterial, antivirus, anti-tumor, and immune modulator activity. Furthermore, its activity as antimicrobial was related to lytic action on bacteria by hydrolyzing the $\beta$ (1-4) bond between $\mathrm{N}$ acetylmuramic and $\mathrm{N}$-ace-tylglucosamine acid in the peptidoglycan layer of the bacteria cell wall. ${ }^{14}$ Glycosidic bond hydrolysis has also led to the formation of small pores in the bacteria cell wall which caused their death. ${ }^{15}$

Although the addition of lysozyme enzyme on toothpaste has been spread in Indonesia, it has not been widely used. Moreover, it also contained active substances such as fluoride, amyloglucosidase, lactoferrin, and lactoperoxidase. ${ }^{16} \mathrm{~A}$ previous experimental study of brushing teeth using fluoride toothpaste which also contained lysozyme, lactoferrin, and lactoperoxidase after a week showed a significant $S$. mutans and $L$. acidophilus decrease $(\mathrm{p}<0.001)$ in children with ECC. ${ }^{17}$

Meanwhile, the addition of lysozyme enzyme active substrate as an antimicrobial on toothpaste increases the efficacy of teeth cleaning procedures, controls plaque, and prevents caries on children, ${ }^{18}$ which becomes an alternative for children below 3 years old. This is because it does not contain fluoride and is safe when accidentally ingested. Therefore, this study aims to compare $S$. mutans antimicrobial activity of lysozyme toothpaste without fluoride on different concentrations which are $0.025,0.05,0.1$, and $0.2 \%$

\section{MATERIALS AND METHODS}

This experimental study was carried out using a post-test design and the ethical clearance was approved by the Ethical Research Committee Faculty of Medicine Universitas Sumatera Utara (USU) no. 59. It was conducted in the Pharmacy lab of Microbiology Department of Faculty of Science and Integrated Lab of Faculty of Medicine, USU. In this study, the toothpaste tested without fluoride at 0.025 , $0.05,0.1$, and $0.2 \%$ concentrations, was lysozyme 
crystals (hen egg white) from Sigma Aldrich. The positive control used were $0.2 \%$ chlorhexidine mouthwash, children's fluoride, and enzyme toothpaste, which are found on markets. Meanwhile, basic substances of tested toothpaste such as calcium carbonate, glycerol, sorbitol, sodium carboxymethyl cellulose, tragacanth, sodium benzoate, flavorings, and distilled water, without additional lysozyme enzyme were used as the negative control.

The tested toothpaste, control, and chlorhexidine mouthwash were analyzed to deter-mine its ability in inhibiting $S$. mutans growth by diffusion method using disc and well and microtiter plate method. The techniques included:

Making bacteria culture and S. mutans dilution $S$. mutans were cultured in TYS20B medium and incubated in a $37^{\circ} \mathrm{C}$ anaerobic jar for $2 \times 24$ hours. After 2 days, bacteria suspension was prepared by placing a single colony in BHI (Brain Heart Infusion), vortexing until homogeneous, and comparing the turbidity to standard $10^{8} \mathrm{Mc}$ Farland solution..$^{19}$ When the culture solution was equivalent to the standard, it was diluted by preparing 7 tubes with $9 \mathrm{ml}$ physiological saline solution and each tube contained $5 \mathrm{~mL}$ saline solution. Subsequently, $1 \mathrm{~mL}$ bacteria were taken from the dilution, placed in the first tube, and vortexed. Approximately $1 \mathrm{~mL}$ was also taken from the first tube to be put in the second tube, and until the seventh tube, where $5 \mathrm{~mL}$ was taken and placed in the eighth tube (containing $5 \mathrm{~mL}$ saline), then vortexed. ${ }^{20}$

Diffusion method using a disc with toothpaste in solid medium. Approximately $1 \mathrm{ml}$ of diluted $S$. mutans (eight tubes) was put on TYS20B agar petri dishes and the bacteria solution was allowed to spread on the agar surface. The disc containing toothpaste, which was previously soaked for 1 hour was later put on the surface. Subsequently, the petri was incubated in an anaerobic jar under $37^{\circ} \mathrm{C}$ temperature for $3 \times 24$ hours, while the inhibition zone (light zone) appeared around the disc, and was counted in mm by caliper. ${ }^{20}$

Diffusion method using well with toothpaste in solid medium. Diluted $1 \mathrm{ml}$ of $S$. mutans was put on agar petri dishes and the bacteria solution was spread to the surface. The medium was punched by using a perforator with $6 \mathrm{~mm}$ diameter, the hole was also filled by toothpaste, and $0.2 \%$ chlorhexidine 0.05 $\mathrm{mg}$. After the petri dish was incubated for 24 hours under $37^{\circ} \mathrm{C}$ temperature, the inhibition zone was measured using caliper in 3 ways, namely horizontally, vertically, and diagonally. ${ }^{21}$

Microtiter plate method Approximately 1-2 colonies of S. mutans colonized in TYS20B agar me- dium were put in a tube containing $30 \mathrm{ml}$ TYS20B liquid medium. Subsequently, the medium was incubated for 24 hours under $37^{\circ} \mathrm{C}$ temperature, while the remaining was agitated at $120 \mathrm{rpm}$.

After 24 hours, the $0.5 \mathrm{~mL}$ TYS20B liquid medium containing $S$. mutans was moved into the tube of $4.5 \mathrm{~mL}$ liquid TYS20B, while dilution was conducted until $10^{4} \mathrm{CFU} / \mathrm{mL}$ and homogenized by shaking. In each well, $200 \mu \mathrm{L}$ liquid TYS20B and lysozyme powder active substances were put, which had been diluted by nuclease-free water to make 50 $\mu \mathrm{L} 0.025,0.05,0.1$, and $0.2 \%$ concentrations. The $0.2 \%$ chlorhexidine of $50 \mu \mathrm{L}$ was put in the fifth well as a positive control, while negative controls were $250 \mu \mathrm{L}$ TYS20B liquid solution with $S$. mutans in the sixth and without in the seventh well. Subsequently, incubation was carried out for 48 hours in the incubator.

The bacteria in each well were removed and the wells were rinsed with $275 \mu \mathrm{L}$ sterile aqua dest 3 times after 48 hours. The wells were further fixed heat in the oven at $70^{\circ} \mathrm{C}$ temperatures for 20 minutes. Subsequently, $250 \mu \mathrm{L}$ sterile violet crystals of $0.1 \%$ $\mu \mathrm{L} / \mathrm{U}$ concentration were added to the well and soaked for 1 minute. The violet crystals were removed and the well was washed 3 times using 275 $\mu \mathrm{L}$ of $95 \%$ ethanol. On the last wash, $95 \%$ ethanol was soaked in the well for 2 minutes before being removed. Then, the optical density of the antibiofilm of lyso-zyme on the $S$. mutans was read by a spectrometer on $575 \mathrm{~nm} .{ }^{22}$ Meanwhile, the analysis test used in this study was Anova one way with Bonferroni post hoc test on $\mathrm{p}<0.05$ level of significance.

\section{RESULTS}

The inhibition zone diameter from the disc method in the TYS20B medium showed that the highest diameter mean was from the tested lysozyme toothpaste of $0.1 \%$ concentration, although $0.2 \%$ concentration was not significantly different. However, this inhibition zone diameter was still lower than the enzyme toothpaste, children's fluoride toothpaste, and $0.2 \%$ chlorhexidine (see Table 1 ).

According to the well method, the highest inhibition zone was discovered on fluoride toothpaste, followed by $0.2 \%$ chlorhexidine, as well as $0.1 \%$, $0.05 \%, 0.2 \%$, and $0.025 \%$ lysozyme toothpaste in the last place $(\mathrm{p}<0,05)$ (see Table 2).

The microtiter plate method showed that the highest antibiofilm was on chlorhexidine mouthwash, followed by $0.2 \%$ lysozyme solution, as well as $0.1 \%, 0.05 \%$, and $0.025 \%$ lysozyme (see Table 3 ). 


\section{DISCUSSION}

In this study, the tested $S$. mutans isolated and cultured from children with ECC were the main agent of caries etiology, ${ }^{23}$ Their antibacterial substances used in this toothpaste was lysozyme, a strongly cationic protein capable of mediating bacterial aggregation, inhibiting adhesion, and also activating autolysin by destructing their cell wall. ${ }^{14,15}$ Meanwhile, the lysozyme activity remains when the enzyme is absorbed in the pellicle. ${ }^{24}$

The source of lysozyme used were crystals from hen egg-white, meanwhile, their variety can affect the result. Although human lysozyme is 3-4 times more reactive than hen egg white lysozyme (HEWL), it is very similar to human lysozyme and contains 129 amino acids (14,3 kDa). Since it is not expensive and has a good correlation to human lysozyme, it is often used in different studies as a substitute. $^{25}$

Based on the results of the disc method, the lysozyme toothpaste in various concentrations had an inhibitory effect on the growth of $S$. mutans. The highest inhibition zone diameter to $S$. mutans was on $0.1 \%$ lysozyme toothpaste with a mean of 13.24 $\mathrm{mm}$, followed by $0.2 \%$ concentration with $12.6 \mathrm{~mm}$ mean $12.6 \mathrm{~mm}, 0.05 \%$ (mean $12.04 \mathrm{~mm}$ ), and $0.025 \%$ concentration (mean $9.06 \mathrm{~mm}$ ) in the last place (Table 1). According to Indonesian Health Ministry, a substance is said to have antibacterial activity when the inhibition diameter is equal to or higher than $6 \mathrm{~mm} \cdot{ }^{26}$ Also, Davis and Stout ${ }^{27}$ stated that antibacterial activity criteria with inhibition zone diameter of $5 \mathrm{~mm}$ or less are categorized as weak, 5$10 \mathrm{~mm}$ is medium, $10-20 \mathrm{~mm}$ is strong, and $20 \mathrm{~mm}$ or more is very strong. Based on these criteria, the inhibition zone of $0.05,0.1$, and $0.2 \%$ lysozyme concentration against $S$. mutans in the toothpaste is categorized strong, while $0.025 \%$ concentration is medium.

According to Bonferroni's post hoc result, there was no mean difference of inhibition against $S$. mutans among lysozyme concentrations. Meanwhile, there was a difference in inhibition against $S$. mutans in various concentrations of lysozyme and children's fluoride toothpaste $(p<0.05)$, but no difference when compared to the enzyme type. Inhibition to $S$. mutans of lysozyme was still not comparable to children's fluoride toothpaste on the market (positive control) but to the enzyme toothpaste (Table 1). Moreover, the children's fluoride toothpaste contains Sodium Lauryl Sulphate (SLS) detergent substance, which is widely used due to its stability, antibacterial aspect, and low surface tension that facilitates paste flow to whole teeth parts. ${ }^{28}$ This detergent contained fluoride as antibacterial for $S$. mutans, therefore, its inhibition was the highest compared to enzyme toothpaste as a positive control. Although enzyme toothpaste available in the market also contains fluoride, it does not contain SLS detergent, which causes oral cavity mucosal desquamation, ulceration, and dry mouth. ${ }^{29}$

This was also shown in the well method, where all lysozyme toothpaste concentrations had inhibition of $S$. mutans growth. Based on the results, there was no difference of inhibition to $S$. mutans among various lysozyme toothpaste concentrations compared to the positive control, except for $0.025 \%$ concentration $(p<0.05)$. The highest mean of inhibition was in $0.1 \%$ concentration $(19.23 \mathrm{~mm})$, followed by $0.05 \%$ $(15.93 \mathrm{~mm})$, and $0.2 \%(15.23 \mathrm{~mm})$ (Table 2).

According to the microtiter plate method, lysozyme solution of $0.025,0.05,0.1$, and $0.2 \%$ concentrations had inhibited $S$. mutans bacteria $(\mathrm{p}<0.05)$. However, $0.025 \%$ lysozyme solution inhibited differently compared to $0.2 \%$ solution ( $\mathrm{p}=0.043$ ), while there was no different inhibition between 0.05 and $0.1 \%$ concentration compared to $0.2 \%$ lysozyme concentration. The highest inhibition of $S$. mutans was discovered in $0.2 \%$ concentration, followed by $0.1 \%$ and $0.05 \%$, therefore, the higher the lysozyme concentration, the higher the inhibition of S. mutans (Table 3).

Based on the 3 methods of $S$. mutans anti-bacterial activity examination, $0.05,0.1$, and $0.2 \%$ lysozyme toothpaste could be used as an alternative for children. This is similar to a previous study that showed the use of lysozyme concentration in toothpaste ranged between $0.01-0.1 \%{ }^{30}$ Similarly, Sing et.al ${ }^{31}$ discovered that the required concentration in inhibiting bio-film formation was in the 50-200 $\mu \mathrm{g} / \mathrm{ml}$. A study by Andrade et.al. ${ }^{13}$ also discovered the bactericidal and bacteriostatic effects of lysozyme against $S$. mutans were $68.5 \mathrm{mg} / \mathrm{mL}$ (MBC concentration) and $58.7 \mathrm{mg} / \mathrm{mL}$, respectively. Tonguc-Altin et.al also described that toothpaste containing lysozyme and lactoferrin has the highest inhibitory effect on the Mutans Streptococci and Lactobacili. $^{32}$

According to the disc and well method, it is concluded that the mean of $S$. mutans antibacterial activity from $0.1 \%$ lysozyme toothpaste was the highest of all three concentrations. However, the microtiter plate method showed that the mean of $S$. 
mutans antibacterial activity was the highest in $0.2 \%$ concentration. Therefore, during the bulk production of toothpaste, the $0.1 \%$ lysozyme can be used as an alternative for children below 3 years old.

\section{ACKNOWLEDGMENT}

The authors are grateful to the Minister of Research, Technology, and Higher Education of Indonesia for funding this study through the DRPM Directorate General of Strengthening Risbang in 2018.

\section{TABLES}

Table 1. Inhibition Zone Diameter to S. mutans from Various Tooth Pastes and Chlorhexidine Used Disc Method

\begin{tabular}{lcccccc}
\hline \multirow{2}{*}{ Test Group } & \multicolumn{5}{c}{ Inhibition zone diameter to $S$. mutans $(\mathrm{mm})$} \\
\cline { 2 - 7 } & Repetition & Repetition & Repetition & Means & SD & $\mathrm{p}$ \\
& I & II & III & & & \\
\hline Lysozyme 0.025\%(A) & 9.9 & 10 & 7.5 & 9.06 & 1.18 & \\
Lysozyme 0.05\%(B) & 11.4 & 10 & 15.3 & 12.04 & 1.24 & \\
Lysozyme 0.1\%(C) & 14.6 & 10.6 & 15 & 13.24 & 1.21 & \\
Lysozyme 0.2\%(D) & 15.6 & 8.6 & 15.2 & 12.68 & 1.4 & $0.000^{* 1}$ \\
Children enzyme toothpaste(E) & 10.55 & 16.9 & 14.8 & 14.08 & 1.27 & \\
Children fluoride toothpaste(F) & 28.15 & 30.4 & 25.8 & 28.05 & 1.08 & \\
Chlorhexidine 0.2\%® $(\mathrm{G})$ & 19.25 & 23 & 25.5 & 22.43 & 1.15 & \\
Negative control & 0 & 0 & 0 & 0 & & \\
\hline
\end{tabular}

* Significant; ${ }^{1}$ Anova one-way test (log 10 transformation); Bonferroni Post Hoc Test: A vs F=0.000; Avs G=0.002; B vs $\mathrm{F}=0.005 ; \mathrm{C}$ vs $\mathrm{F}=0.014 ; \mathrm{D}$ vs $\mathrm{F}=0.008 ; \mathrm{E}$ vs $\mathrm{F}=0.022$

Table 2. Inhibition Zone Diameter to $S$. mutans from Various Tooth Pastes and Chlorhexidine Used Well Method

\begin{tabular}{lcccccc}
\hline \multirow{2}{*}{ Test Group } & \multicolumn{7}{c}{ Inhibition zone diameter to S. mutans $(\mathrm{mm})$} & & \\
\cline { 2 - 7 } & Repetition & Repetition & Repetition & Means & SD & $\mathrm{p}$ \\
& I & II & III & & & \\
\hline Lysozyme 0.025\% (A) & 0 & 6.5 & 9.2 & 5.23 & 4.73 & \\
Lysozyme 0.05\% (B) & 14.2 & 17.8 & 15.8 & 15.93 & 1.80 & \\
Lysozyme 0.1\% (C) & 23 & 15.8 & 18.9 & 19.23 & 3.61 & \\
Lysozyme 0.2\% (D) & 11.2 & 18.5 & 16 & 15.23 & 3.71 & $0.03 * 1$ \\
Children enzyme tooth paste (E) & 11.4 & 14.15 & 20.2 & 15.37 & 4.46 & \\
Children fluoride tooth paste (F) & 17.9 & 35.85 & 32.2 & 28.65 & 9.49 & \\
Chlorhexidine 0.2\%® (G) & 17.1 & 22.3 & 28 & 22.47 & 5.45 & \\
Negative control & 0 & 0 & 0 & 0 & 0.00 & \\
\hline *Significant ${ }^{1}$ Anova one way test, Bonferoni Post Hoc Test= A vs F=0.002; A vs G=0.026
\end{tabular}

*Significant ${ }^{1}$ Anova one way test, Bonferoni Post Hoc Test $=$ A vs F=0.002; A vs $\mathrm{G}=0.026$

Table 3. Optical Density (nm) of Anti-biofilm of Lysozyme on the S. mutans from Various Concentrations of Lysozyme Solution and Chlorhexidine Used Microtiter Plate Method

\begin{tabular}{lcccccc}
\hline \multirow{2}{*}{ Test Group } & \multicolumn{4}{c}{ Optical density $(\mathrm{nm})$ of anti-biofilm of S. mutans } & \\
\cline { 2 - 5 } & Repetition & Repetition & Repetition & Means & SD & $\mathrm{p}$ \\
& I & II & III & & & \\
\hline Lysozyme Solution $0.025 \%$ (A) & 0.5379 & 0.5270 & 0.6246 & 0.5632 & 0.05 \\
Lysozyme Solution $0.05 \%$ (B) & 0.6201 & 0.5070 & 0.3900 & 0.5057 & 0.115 \\
Lysozyme Solution 0.1\% (C) & 0.3481 & 0.5744 & 0.5376 & 0.4867 & 0.121 \\
\hline
\end{tabular}




\begin{tabular}{lllllll} 
Lysozyme Solution $0.2 \%(\mathrm{D})$ & 0.2232 & 0.3295 & 0.2892 & 0.2806 & 0.054 & $0.000 * 1$ \\
Chlorhexidine $0.2 \%((\mathrm{E})$ & 0.0510 & 0.0506 & 0.0488 & 0.0506 & 0.001 & \\
Negative Control (with $S$. mutans) $(\mathrm{F})$ & 0.5756 & 0.6569 & 0.7552 & 0.6626 & 0.090 \\
Negative Control (without $S$. mutans) $(\mathrm{G})$ & & & & & & \\
& 0.5925 & 0.8521 & 0.7202 & 0.7216 & 0.130 \\
\hline
\end{tabular}

*Significant ${ }^{1}$ Anova one way Test; Bonferroni Post Hoc Test: A vs D=0.043; A vs E= 0.000; B vs E= 0.001; C vs $\mathrm{E}=0.001 \mathrm{G}$ vs $\mathrm{D}=0.001 ; \mathrm{G}$ vs $\mathrm{E}=0.000 ; \mathrm{F}$ vs $\mathrm{D}=0.003 ; \mathrm{F}$ vs $\mathrm{E}=0.000$

\section{REFERENCES}

1. American Academy of Pediatric Dentistry (AAPD). Policy on early childhood caries (ECC): Classifications, consequences, and preventive strategies. Refer Man 2014, 37 (6): 50-2.

2. Zhou Y, Lin HC, Lo ECM, Wong MCM. Risk indicators for early childhood caries in 2-year-old children in southern China. Australian Dent J 2011, 56: 33-9.

3. Kumarihamy SLM, Subasinghe LD, Jayasekara P, Kularatna SM, Palipana PD. The prevalence of early childhood caries in 1-2 years olds in a semi-urban area of Sri Lanka. BMC Research Notes 2011, 4:336.

4. Peltzer K, Mongkolchati A. Severe early childhood caries and social determinants in three-year-old children from Northern Thailand: a birth cohort study. BMC Oral Health 2015, 15:108.

5. Badan Penelitian dan Pengembangan Kesehatan Kementrian Kesehatan RI. Riset kesehatan dasar 2007; http://litbang.depkes.go.id, Accessed 2014 October 19.

6. Badan Penelitian dan Pengembangan Kesehatan Kementrian Kesehatan RI. Riset kesehatan dasar 2013.; http://litbang.depkes.go.id, Accessed 2014 October 19.

7. Octiara E, Tamba EA. Hubungan ekonomi keluarga dan pendidikan ibu dengan Early Childhood Caries (ECC) anak usia 12-36 bulan di Kecamatan Medan Denai. Dentika Dent J 2012,17: 79.

8. Egle S, Milciuviene S, Narbutaite J, Vasiliauskiene I, Andruskeviciene V, Bendoraitiene EA et al. Severe ECC and behavior risk factors among 3 years old children in Lithuania. Medic. Kaunas Lithuania 2010, 46(2): 135-41.

9. Vejdani J, Hadipoor Z, Leyli EK. Risk factors for severe early childhood caries in 2-3-year-old children in Rasht. J Dentomaxilllo Radiolog Pathol and Surg 2014, 2 (4): 15-22.

10. American Academy of Pediatric Dentistry (AAPD). Guideline on fluoride therapy. Refer Man 2014, 37 (6): 15,16 .

11. Wang MCM, Glenny AM, Tsang BWK, Worthington HV, Marinho VC. Topical fluoride as a cause of dental fluorosis in children. The Cohrane Libr 2009, 2: 1-7.

12. Olatosi OO, Inem V, Sofola OO, Prakash P, Sote EO. The prevalence of early childhood caries and its associated risk factors among preschool childre referred to a tertiary care institution. Nigerian J Clin Pract 2015, 18: 494-501.

13. de Andrade FB, de Oliveira JC, Yoshie MT, Guimarães BM, Gonçalves RB, Schwarcz WD. Antimicrobial activity and synergism of lactoferrin and lysozyme against cariogenic microorganisms. Braz Den. J 2014, 25:165-9.

14. Zalewska A, Knaś M, Szulimowska J,Waszkiewicz N, Wołosik K,Waszkiel D. Nonspecific immune factors in the whole unstimulated saliva of human infants, children and adolescents. Dent Med Probl 2013, 50(3):291-7.

15. Moslemi M, Sattari M, Kooshki F, Fotuhi F, Modarresi N, Sadrabad ZK et.al. Relationship of Salivary lactoferrin and lysozyme concentrations with early childhood caries. J Dent Res Dent Clin Dent Prospect 2015, 9(2):109-14.

16. Enzim. Komposisi, harga, pasta gigi enzim toothpaste mint, enzim toothpaste orthodontic. https:// sakitgi2.blogspot.com > Pasta Glgi > Pasta Gigi Enzim, Accessed 2016 November 24.

17. Gudipaneni RV, Vijay KV, Jesudass G, Peddengatagari S, Duddu Y. Short term comparative evaluation of antimicrobial efficacy of tooth paste containing lactoferrin, lysozyme, lactoperoxidase in children with severe early childhood caries: A clinical study. J Clin and Diagn Resear 2014, 8(4): ZC18-20.

18. Gautam B, Dongol E, Shrestha A. In vitro antimicrobial activity of different toothpastes. J Kathmandu Med Coll 2017, 6(2): 52-8.

19. Afni N, Said N, Yuliet. Uji aktivitas antibakteri pasta gigi ekstrak biji pinang (Areca catechu L.) terhadap Streptococcus mutans dan Staphylococcus aureus. GALENIKA J Pharmacy 2015, 1 (1): 48 - 58.

20. Mangundjaja S, Archinantianingsih S, Alexander A. Effect of dentrifice containing enzyme on mutans of S. mutans isolated from school children harbouring species in Palembang. Pertemuan Ilmiah Tahunan Perhimpunan Mikrobiologi Indonesia. Semarang, 2004: 1-6.

21. Smolarek PC, Esmerino LA, Chibinski AC, Bortoluzzi MC, dos Santos EB, Kozlowski Junior VA. In vitro antimicrobial evaluation of toothpastes with natural compounds. Eur J Dent 2015, 9(4): 580-6.

22. O'Toole GA. Microtiter dish biofilm formation assay. J Visualized Experiments: JoVE 2011, 47: e2437 
23. Daboor SM, Masood FSS, Al-Azab MS, Nori EE. A review on Streptococcus mutans with its diseases dental caries, dental plaque and endocarditis. Indian J Microbiol Res 2015, 2(2):76-82.

24. Svendsen IE, Lindh L, Arnebrant T. Adsorption behaviour and surfactant elution of cationic salivary proteins at solid/liquid interfaces, studied by in situ ellipsometry. Colloid and Surf B: Biointerf 2006, 53: $157-66$

25. Cao D, Wu H, Li Q, Sun Y, Liu T, Fei J et.al. Expression of recombinant human lysozyme in egg whites of transgenic hens. Plos One 2015: 1-15.

26. DepKes RI. Materia Medika Indonesia. Jilid Ke V. Jakarta: Ditjen POM, 1989

27. Davis WW, Stout TR. Disc plate method of microbiological antibiotic assay. I. Factors in influencing variability and error. Novel procedure offering improved accuracy. Appl Microbiol 1971, 22 (4):65970 .
28. Harris NO and Garcia-GodoyF. Primary preventive dentistry. New Jersey: Pearson Education Inc, 2004: 123-7.

29. Macdonald JB, Tobin CA, Hurley MY. Oral leukoedema with mucosal desquamation caused by toothpaste containing sodium lauryl sulfate. Cutis 2016,97(1): E4,5.

30. CN1720891A. Enzyme-containing toothpaste and its preparing process. http://www.google.co.id/ patents/CN1720891A?cl, ( 24 November 2016).

31. Singh PK, Parsek MR, Greenberg EP, Welsh MJ. A component of innate immunity prevents bacterial biofilm development. Nature 2002, 417: 552-5.

32. Tonguc-Altin K, Sandalli N, Duman G, SelviKuvvetli S, Topcuoglu N, Kulekci G. Development of novel formulations containing Lysozyme and Lactoferrin and evaluation of antibacterial effects on Mutans Streptococci and Lactobacilli. Archieves of Oral Biology 2015; 60 (5): 706-14. 